\title{
Treacher-Collins 症候群の一例
}

\author{
大阪大学医学部耳鼻喉咽科学教室 \\ （主任：内藤 㩦教授） \\ 杉山 茂夫, 中島 礼士, 小田 隆造
}

\section{I 緒带}

顔面の先天的畸型にはいろいろあるが，その一つに Treacher-Collins 症候群がある。本症候群注眼裂の外 側下方えの傾斜, 䫑骨と下顎骨の発育不全のために, 一見特徴のある顔貌を呈する。症例によっては聴器の 畸型，口盖の異常，歯列異常，毛髮の異常，四股の渏 型などを種くの程度に合併することが多い。もともと 特徴ある眼症状から眼科領琙で多く報告されてきた が，耳鼻喉咽科医にとっても聴器の畸型に興味を惹か れる疾患である。しかも最近の Otomikrochirurgie の 発達はこの聴器に手術をおこない，聴力改善をある程 度可能ならしめた。

最近, われわれは伝音性難聴を伴ら典型的な Treacher-Collins 症候群に遭遇し，その一側に Tympanotomie をほどこす機会を得ることができた。るってそ の経過定報告すると共に，過去の手術例に照合して文 献的考察加えた。

\section{II 症例}

患者: 22 才女子, 独身, 無職

初診：昭和 45 年 6 月 11 日

主訴：両難聴拈よび耳鳴

\section{[現病櫪]}

幼時より両側の難聴と耳鴻があり，特に変化を示す ことなく現在に至っている。そのために特に診察を受 けたことはない。他の耳症状, すなわち耳痛, 耳漏, 眩量などはない。

\section{[既往歷]}

幼時より健康で著患を知らず成人している。しかし， 昭和45年 5 月26日に当院口腔外科で, Vogelgesichtに 対して腸骨移殖による下顎形成術をうけている。

\section{[家族歴]}

父母ともに健在，他の同胞 4 人も健康で特に著変を みない。

\section{[現症]}

本患者の特徴的所見はその顔貌である。すなわち， 左右の眼裂は外側下方へ傾斜し，特に外方 ${ }^{1 / 3}$ に著明で ある。したがって眼裂は全体として八字型を呈してい る(図 1)。また, 頰骨と下顎骨の発育が不完全で小さ く，下顎部には口胵外科で受けた下顎形成術による洀 㾗をみる。

再側の外耳道はきわめて苵く，小巟用朝顔型の耳鏡 を雨入し得る程度であった。外耳道狭窄はおもに外半 部で，内半部はやや広くなりやっと鼓膜を見ることが できる。鼓膜にはツチ骨柄, 短突起, 光雓などは全く 見られない。全体が薄い紫赤色の膜で，緊張部と弛緩 部も区別できなかった。なお，両側の耳介は形状，位 置とも正常であった。

鼻咽頭には特記すべき所見はなかった。

[祫查成續]

(i) 聴力検督

骨導はよく聴取しらるが，気導は $50 \sim 60 \mathrm{~dB}$ 低下の ほぼ水平型をとる典型的な伝音性難聴を示す(図 2)。

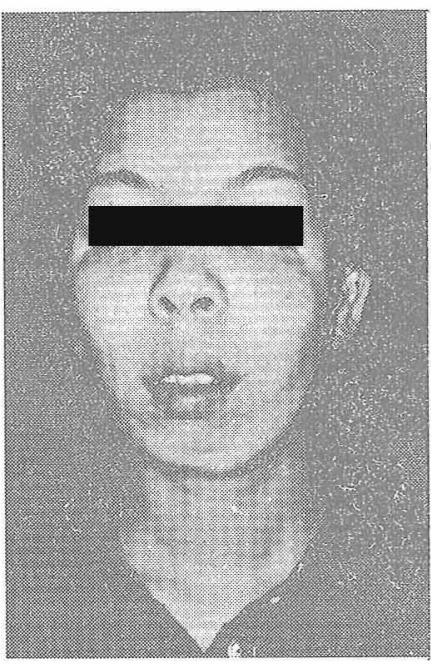

図 1 


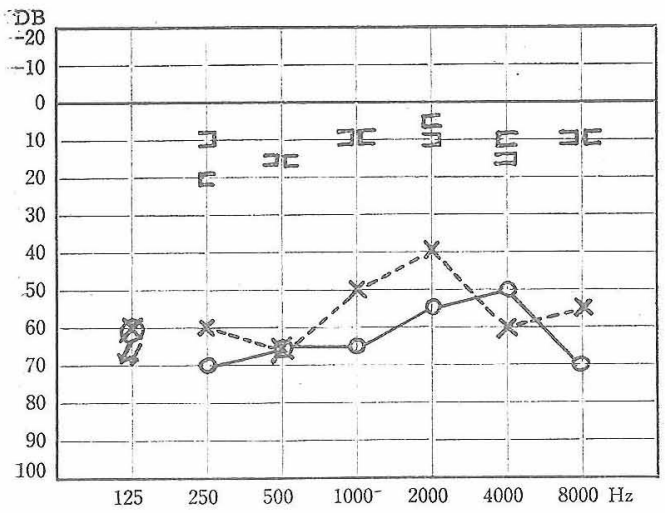

図 2

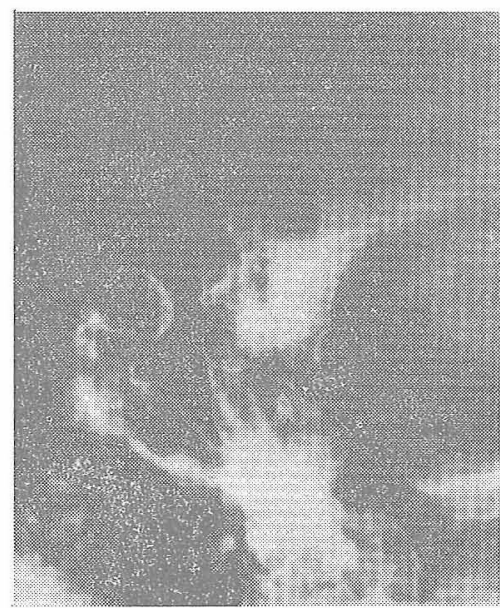

娄 3

Gellé の检査は左右とも陽性であった。

(ii) X線検督

两側の乳突蜂栄は硬化型で，蜂栄の発育は全く認め られなかった。S状洞の位琵は正常で，骨破壊像もな かった(図 3)。，下顎骨体は小さく形成不全が著明であ り，中央に移殖骨が認められる。棈造上，石灭沈着は 良好であった。顂骨拉よび奘形骨にも軽度の形成不全 が見られた。

\section{(iii) その他}

血液一般, 血液化学, 新鮮尿, 胸部X線, 肝機能, 心電図などには全く異常所見を認めなかった。

\section{F術乩よび経過}

插管庥酔のもとに左の Tympanotomie をおこなっ た。皮切は耳介縁にそっておき, Meatotympanoplastik の要領で外耳道皮膚を剝離した。外耳道の骨性凑窄部

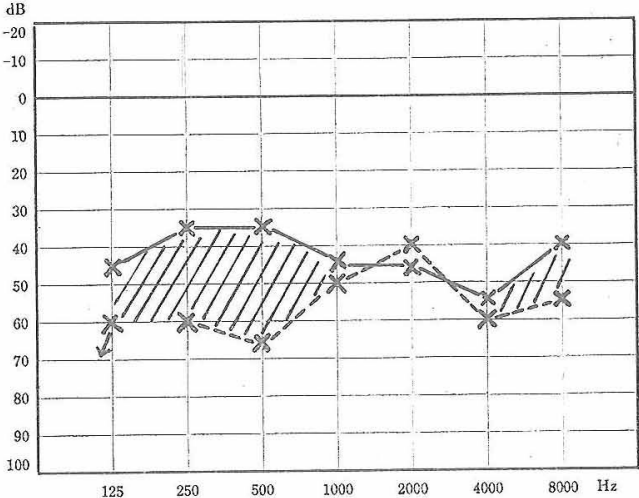

圈 4

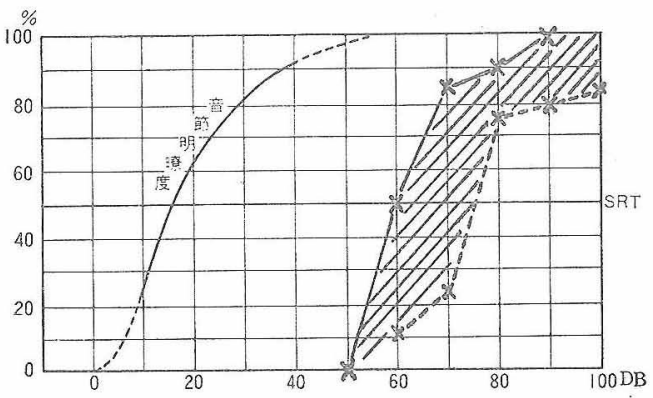

圈 5

は，前壁を除き全周にわたって削除し，外耳道形成術 (Meatoplastik) をおこなった。ついで外耳道皮虔をつ けたまま，鼓慕を鼓膜輪よりはづし，前方に翻転しよ うとした。しかし，敬室腔は見えず，鼓膜の下にすぐ 骨性部分があり竗膜と癒着していた。穿孔を起すこと なく剥離することは不可能であったので鼓膜を除去し た。鼓膜はきわめて薄く，面積は通常の約半分と思わ れた。

鼓膜直下の骨面は中央で上下にやや膨隆し，前後に 小さな凹部がありその中に少量の肉芽が存在した。肉 芽を除去すると其に，中央の骨性部分学鋭匙で注意樑 く削開したこころ，浮腫状を是する粘膜を充満した腔 が出現した。浮腫状粘慕て除去していくと，上部に一 列に並ぶ二つの小骨があった。可動性を保持している ため，これがッチ骨とキヌタ骨と思われるが，それに つづくアブミ骨らしきものはない。したがって二つの 小骨を錯子で除去したが，ただ細長い骨で聴小骨の形 態はとどめていなかった。さらにさがしてタたが，ア ブミ骨，前庭密，蝸牛管，耳管口などはついに発見で きなかった。露出骨面全体に筋膜をおさ術索終った。

術後は発熱，眩畩などもなく，順調な経過をたどっ 
た。2 週間後にはタンポンを除去したが，自覚的には 術前よりょく聴えるという。術後18日目に聴力検查を 行ったが，主として低音部で軽度の改善が認められた （図 4 ）。語音聴力でもやはり柽度の改善があった（図 5 )。オージオグラムでは破線が術前の, 実線が術後の 聴力を示す。

約 1 月後にはほとんど乾燥し，交換の必要もなくな ったので退院した。

\section{IV 考按}

Treacher-Collins 症候群は, Berry (1889)が特徴のい ちじるしい顔面畸型を有する 2 症例を記載したのが最 初であり, Collins(1900)が 2 症例を追加してTreacherCollins 症候群として発表した。顔面のみならず頭蓋, 軀幹，四股などの先天性畸型を伴う場合は，主たる病 変部位を基にして dysostosis craniofacialis, dysostosis maxillofacialis, dysostosis mandibulofacialis, dysostosis mandibularis, dysostosis acrofacialisなどに分頪されて いる。そのらちの一部は，Treacher-Collins 症候群の よ5に，報告者の名前を冠して Crouzon 症候群， Franceschetti 症候群とも呼ばれる。著者らは今回の報 告例に Treacher-Collins 症候群といら名称をもちいて いるが，顔面畸型を主病変とする場合はこの名称が多 くもちいられており，もっとも普遍的なようである。

また，報告例が増すと共に合併するいろいろな渏型 が発見され，本症候群に包含されている。たとえば，
人によっては外耳の畸型，時には中，内耳の畸型も含めて本症候群としている。しかし，聴器畸型のない症： 例もあり，共通かつ特有の所見だけを以って本症候群 と考えるべきであろら。その所見は次の二つである。

1）眼裂が外下方に傾斜し，全体として特有の八字: 型を呈する。

2）煩骨と下㖽の発育不全が著明で，全体として Vogelgesicht を呈する。

この眼症状と Vogelgesicht をもつ特有の顔貌を備え ていれば，Treacher-Collins 症候群と考えられる。他， の畸型㹥合併症と考えて差支えなからう。

合併する畸型のうち，われわれ耳鼻科医にとって最 も興味あるのは耳症候である。聴器の畸型を最初に報 告したのは Pires de Lima (1932)であり，本邦では大 和田(1957)である。本邦での報告は20余例であるが， 多くの場合になんらかの聴器畸型を合併している。そ して聴力障害としてはほとんど伝音性難聴である。坂 本ら (1963)は 4 症例を報告して扤り，軽度の耳畸型 を認めるのみで，外耳道や鼓膜は正常であったにもか かわらず，全例に伝性音難聴があったと述べている。 著者らの症例も外耳道畸型と伝音性難聴を有してい た。外耳道がきわめて狭いため,このままでは補聴器 を使用することもできず，また耳小骨連鎖の畸型も考 えられるので, Tympanotomie を行ったものである。 中耳の畸型は高度で，耳小骨浪跡的であり，鼓膜の 下に骨性板を認めた。前庭空と蝸牛空が発見できなか

表 1

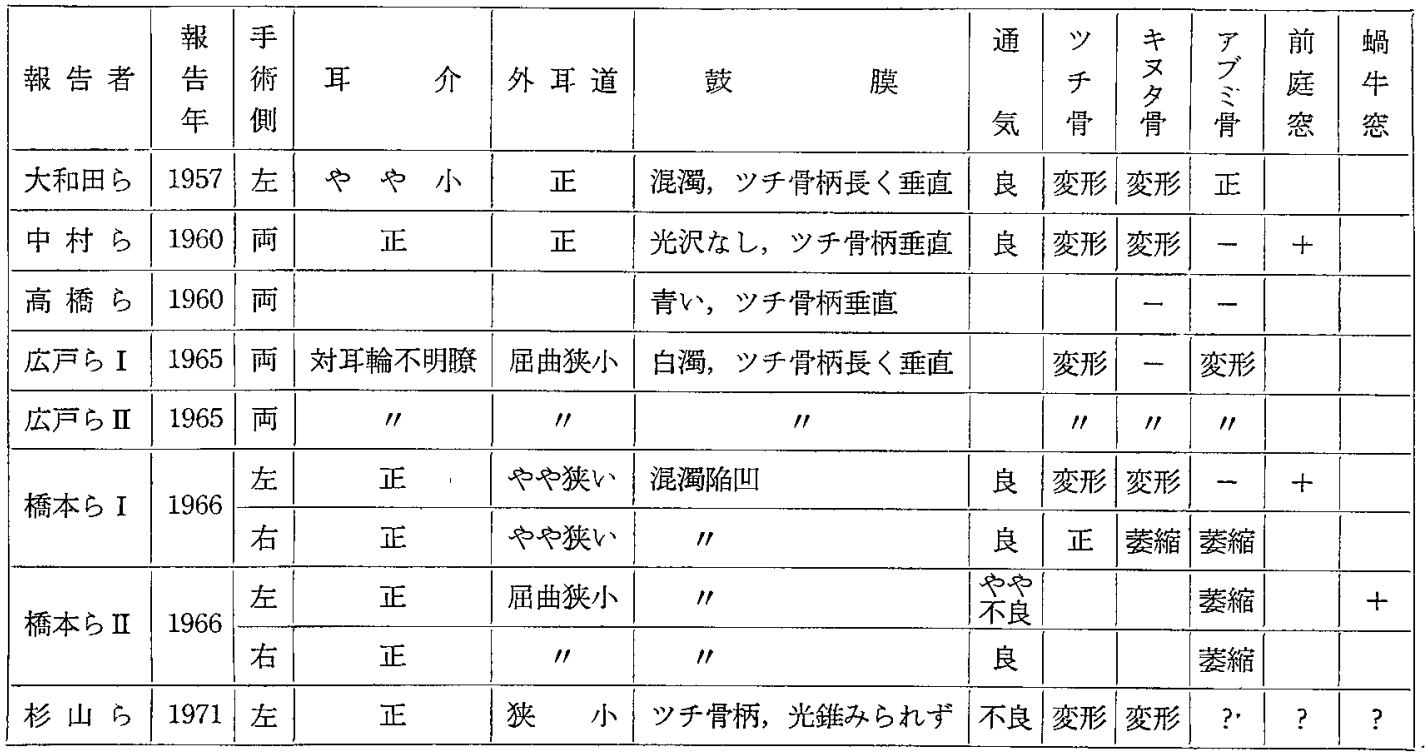


ったため，いわゆる聴力増進手術はできなかった。 オージオグラムの上で, 術前後で軽度の改善が認め られた。これは前庭空と螖牛空は発見できなかったけ れどもどこかに存在し，移殖した筋膜が Wullsteinの IV 型のような効果を生んだためではないかと想像し得 る。

本邦での手術例は, 著者の調べたところでは表 1 に 示したように8 例14耳であった。14耳の手術例に共通 のことは，耳耹檤の異常の有無にかかわらず， 耳小骨にはなんらかの異常が認められることである。 アブミ骨では正常 1 耳, 変形 7 耳, 欠損 6 耳となる。 大和田ら(1957)は耳硬化症と考えていたが，手術によ って耳小骨畸型であることが判明したとのべ，耳小骨 の変形はツチ骨とキヌタ骨で, アブミ骨は存在し，こ れに綿花をあてることにより著明な聴力改善を認めて いる。中村ら（1960）は両側の手術例を報告している が, 両側ともアブミ骨はなかったが, 前庭空は認められ たと記載している。したがって,これらの症例では工夫 した手術がほぎこされているが，著者らの場合は聴力 を改善する手がかりがなく，外耳道成形(Meatoplastik) により補㯖器の使用が可能となった点が救ひである。

その他の合併症についても色々な報告がある。 Berry（1889）は鬼唇の合併例を, 黒住ら (1956) は斜 走口盍裂をもつ珍しい症例を, 橋本ら（1966）㹥言語 障害と四股畸型の合併例を報告している。著者らの場 合は，伝音性難聴をもつ以外，特にいちじるしい症状 はなかった。

本症候群には不規則な遺伝性がとなえられているが 明確ではなく，遺伝関係が認められる症例の方がむし ろ少い。Gron wall \& Olsson (1954) は不完全型であ る父親と典型的なその子供の症例を報告している。坂 本ら（1963）は果親とその子供(同胞 3 人中の第 2 子) の例を報告している。また広戸ら（1965）は 1 家系 2 世代にわたる 4 例を報告しており，その症例より考察 して優性遺伝形式をとると述へている。著者らの症例 は同胞 5 人中の第 4 子であるが，両親および他の同胞 全員に異常がみられず, 遺伝関倸は証明できなかっ た。

本症の特有な顔貌, 聴器畸型, 乘唇, 口腔内の異常 などの複雑な所見は, 胎生学的に考えればおのずから 理解できる。顔面の発生は殆んど第 1 鰓马に由来する ものであり, 胎生28～29日頃では前頭突起と左右の上 下䫟突起の 5 つの隆起で口窝を囲んでいる。それらの 発育不全抢よび㽷合不全によって, 種々の程度の顔面
畸型となって現われるのである。

聴器伝音系の発生は第 1 鰓弓と第 2 鰓弓に由来する が, 細部ではな抢異論の在するところである。すなわ ち外耳道は第 1 鰓溝から, 鼓膜は第 1 閉鎖膜から, 鼓 室と耳管は第 1 鰓露から発生する。第 1 鰓垔鼓室耳 管になる部分は recessus tubotympanicus と呼ばれて いるが，この外側の大部分が鼓室に，内側の小部分が 耳管となる。この recessus の頭側壁は第 1 鰓弓に, 外 側壁は第 2 鰓马に属することに異論はないが，内側壁 の所属鰓号は明確でない。三田村（1954）はその隆起 の一部注第 3 鰓弓の延長と考えている。

耳小骨のらち、ツチ骨とキヌタ骨は第 1 鰓々下買突 起内の Meckel 氏軟骨から発生する。つまり Meckel 氏軟骨の本体は下顎骨となり，その上端がッチ骨とキ ヌタ骨になる。アブミ骨はこれら 2 小骨と異なり，第 2 鰓马内の Reichert 氏軟骨の上方より生ずる。ちな みにその大部分は processus styloideus となる。

耳介の発生を第 1 ，第 2 鰓衴依存している。すな わち，下顎马と舌骨马の第 1 鰓清よりの縁に， 3 個づ つ 2 列に並ぶ 9 個の隆起を生ずる。この耳介隆起が癒 合して, 胎生 2 力月の末期にはほぼその外形が完成す る。また胎生初期には口裂近くに位置しており, 次第 に外上方に移動する。したがって下顎骨の発育が悪い 時は, 耳介む眼裂の高さよりは低く左右の距離む近く なる。われわれの症例では耳介の形態および位置は正 常であったが，時にその異常を合併することもよく理 解できる。

一般に, 鼓膜が正常に近い伝音性難聴の確定診断は, 時に困難を伴うことがある。しかし最近のいちじる しい手術の進歩と抗性物質の開発により，躊躇なく Tympanotomie を行うことができる。殊に本症候群の ごとき疾患では, 難聴に聴力増進手術を, 顔面には口 腔外科と協力して下顎形成術を進んで行うべきである う。そうすることにより，悩める者に一筋の光明が与 えられるにちがいない。

\section{$\mathrm{V}$ 結 語}

1）典型的な Treacher-Collins 症候群の一例を報告 した。

2）外耳道狭窄と伝音性難聴を有する左耳に Tympanotomie と Meatoplastikを行った。

3）鼓室はほとんどなく, 鼓膜の直下にこれと丞着 する骨性の隔壁があった。ツチ骨とキヌタ骨梳跡的 であり,アブミ骨, 前庭空, 蝸牛空は認められなかっ 
た。

4）したがって，いわゆる恥力増進手術はできなか った。術前後における軽度の聴力改善は，単に骨性の 隔壁を除去したための影響と考えられる。

5）本邦での手術例と比較し，かつ鼓室の状態に胎 生学的考察を加えた。

本論文の要旨は第16回日本オージオロジー学会にお いて発表した。稿を終るに臨み, 内藤教授の御指導, 御校閲を深謝します。

\section{Teracher-Collins Syndrome: Report of a Case Subjected to Tympanotomy By \\ Shigeo Sugiyama, M.D., Reisi Nakajima, M.D. and Ryuzo Oda, M.D.}

From the Department of Oto-Rhino-Laryngology Osaka University School of Medicine

(Director: Prof. T. Naito, M.D.)

A 22-year-old female with typical Treacher-Collins syndrome had an antimongoloid slant of the palpebral fissures, hypoplasia of the malar and mandibular bones, and external acoustic meatuses of pediatric ear speculumpatency. On otoscopic examination, no handle or short process of a malleus, or light cone was seen. The ear drum consisted of thin, purplish-red, membranous tissue showing no differentiation of pars tensa and flaccida. Audiogram showed a typical conductive deafness. Tympanotomy of the left ear disclosed virtual absence of the tympanic cavity with an osseous plate adherent to the tympanic membrane. There was a rudimentary malleus and incus, but no stapes, oval or round window were seen. Postoperatively, a slight improvement in auditory acuity was achieved. This was probably due to the removal of the osseous plate. The patient became possible to use a hearing aid. The present case was compared with other operated cases in Japan, and the anomalous tympanic cavity was discussed from an embryological point of view.

\section{参考文献}

1) Berry, G.A.: Note on a congenital defect (coloboma) of the lower lid. Roy. Lond. Ophthal. Hosp. Rep., 12 ; 255, 1889.

2) Collins, E.T.: Case with symmetrical congenital notches in the outer part of each lower lid and defective development of the malar bones. Trans. Ophthal. Soc., $20 ; 190,1900$.

3) Franceschetti, A. \& Klein, D.: The mandibulofacial dysostosis "a new hereditary syndrome", Acta. Ophthal., 27 ; 143, 1949.

4) Pires de Lima :5) より引用

5）大和田健次郎，他：聴力増進手術を行った，耳小 骨畸形を伴える Dysostosis mandibulofacialis の 1 例。耳㬋, $29 ; 1011,1957$.

6）黑住静之，他：特異な口蓋破裂，顔面横裂，象 唇を伴う Treacher Collins 氏症候群の1例。耳喉, $28 ; 193,1956$.

7）小平英太郎：発生学々奇形。医歯薬出版, 1966.

8）坂本伸一郎，他：家族的に見られた Dysostosis mandibulofacialis $の 4$ 症例。耳喉, $35 ; 555,1963$.

9）高橋宏明，他：先天性耳小骨連鎖異常症の 1 例。 耳鼻臨床，54；204，1960.

10）中村四郎，他：两側鼓室小骨の奇形を伴った Treacher Collins' Syndrome の 1 例。耳喉, 32; 957, 1960.

11）萩場芳雄：Treacher Collins-Franceschetti 氏症 候群の 1 例。耳喉, $32 ； 1055,1960$.

12）橋本泰彦, 他：一家系に生じた Dysostosis mandibulofacialis について。日耳鼻, $69 ; 1485,1966$.

13）広戸幾一郎，他：一家系に多発せる TreacherCollins 症候群。日耳鼻, $68 ； 787 ， 1965$.

14）三田村左智：人胎児鼓室及耳管の発生学的研究。 日医大雑誌，26；204，1958.

15）三田村 踈：人胎览鼓室の発生学的研究。日医大 雑誌，21；471，1954.

16）柳原尚明，他：特異な耳奇形を伴った，偏側性， 不完全型 Dysostosis mandibulofacialis の 1 例。耳 鼻臨床, $56 ; 187,1962$. 